\title{
Rekomendasi Perbaikan Infrastruktur TI di SMK Berdasarkan Evaluasi Tingkat Kematangan dengan Framework Cobit 4.1
}

\author{
Dwiyono Ariyadi ${ }^{1}$, Hendrik Kusbandono ${ }^{2}$, Indah Puji Astuti ${ }^{3}$ \\ 1,3Universitas Muhammadiyah Ponorogo, ${ }^{2}$ Politeknik Negeri Madiun \\ 1,3Jl. Budi Utomo No. 10 Ponorogo, ${ }^{2}$ Jl. Serayu No.84, Pandean, Madiun \\ 1dwiyono_ariyadi@umpo.ac.id, 2h3ndrik57@pnm.ac.id, ${ }^{3 i n d a h s a n .0912 @ g m a i l . c o m ~}$
}

\begin{abstract}
The transfer of management from SMK(SMK) in 2017 by the East Java Provincial Government has an impact on many things. One of them is the need for media for communication. Information technology (IT) infrastructure in Vocational Schools is a connecting between Vocational Schools and the East Java Provincial Education Office. IT facilities can streamline and streamline communication between the Office of Education and Vocational Schools in various regions. To find out the state of IT infrastructure in Vocational Schools in Madiun Regency, there is a need to measure the maturity level of IT infrastructure in SMK. One popular IT governance evaluation framework used is COBIT. With the COBIT framework guidelines can assess current conditions, as well as expectations of what will be achieved. The results of the gap will be used as a basis for recommendations for improvements to what stages have not been in line with expectations. The results of the maturity level of management of IT infrastructure in Vocational High Schools at each school on average at AI3 sub domain are at level 2, while AI5 sub domains are at level 1. As for the situation in AI3 sub domains, there are still some who care about the importance of IT infrastructure policy, responsibility for infrastructure management is still limited to individual intuition, as well as the absence of measurement of the results of the objectives whether it has been achieved. While AI5 sub domain is management has begun to identify procedures for collaboration with IT infrastructure suppliers, there are standard criteria for the selection of IT infrastructure suppliers, and there are fundamental objectives for IT infrastructure supplier contract management.
\end{abstract}

Keyword: Vocational, IT infrastructure, COBIT, sub domain AI3, sub domain AI5

\begin{abstract}
Abstrak
Pengalihan pengelolaan Sekolah Menengah Kejuruan) pada tahun 2017 oleh Pemerintah Provinsi Jawa Timur berdampak pada banyak hal. Salah satunya perluadanya media untuk komunikasi. Infrastruktur teknologi informasi (TI) pada SMK merupakan jembatan penghubung antar SMK dengan Dinas Pendidikan Provinsi Jawa Timur. Sarana TI dapat mempersingkat dan mengefektifkan komunikasi antara Dinas Pendidikan dan SMK yang tersebar di berbagai daerah. Untuk mengetahui keadaan infrastruktur TI di SMK se Kabupaten Madiun perlu adanya upaya pengukuran tingkat kematangan infrastruktur TI di SMK. Salah satu framework evaluasi tatakelola TI yang populer digunakan adalah COBIT. Dengan pedoman framework COBIT dapat menilai kondisi saat ini, serta harapan apa yang akan dicapai. Dari hasil kesenjangan (gap) tersebut akan digunakan sebagai dasar dilakukan rekomendasi perbaikan terhadap tahapan apa yang belum sesuai dengan harapan. Hasil dari tingkat kematangan pengelolaan infrastruktur TI di SMK pada masing-masing sekolah ratarata saat pada sub domain AI3 berada pada tingkat 2, sedangkan sub domain AI5 berada pada tingkat 1.Adapun keadaan pada sub domain AI3 adalah masih sebagian pihak yang peduli terkait pentingnya kebijakan infrastruktur TI, tanggungjawab mengenai pengelola infrastruktur masih sebatas intuisi individu, serta belum adanya pengukuran hasil tujuan apakah sudah tercapai. Sedangkan sub domain AI5 adalah pihak manajemen sudah mulai
\end{abstract}


mengidentifikasi prosedur kerjasama dengan pihak pemasok prasarana TI, adanya kriteria standar bagi pemilihan calon pemasok prasaran TI, serta terdapat tujuan mendasar manajemen kontrak pemasok prasarana TI.

Keyword : SMK, infrastruktur TI, COBIT, sub domain AI3, sub domain AI5

\section{PENDAHULUAN}

Perkembangannya penerapan teknologi informasi (TI) dan komunikasi dalam beberapa dekade akhir ini sangat luar biasa. Hal ini terbukti sangat efektif dalam membantu mencapai tujuan bisnis organisasi. Peran TI sebagai sarana pendukung berpengaruh besar terhadap seberapacepatorganisasi dalam pencapai tujuan nya.Keberadaan TI di lingkungan pendidikan juga telah diterapkan hampir di semua sekolah, salah satunya Sekolah Menengan Kejuruan (SMK). Peralihan SMK dikelola oleh propinsi per periode 2017, mengharuskan segala pengarsipan administrasi lembaga sekolah berbasis TI untuk dilaporkan ke dinas pendidikan provinsi (pusat). Selain itu di lingkungan internal sendiri, pihak sekolah harus mampu melayani warganya. Pelayanan kebutuhan administratif, prasarana pendukung KBM dan aktivitas kebutuhan sekolah. Untuk keberlangsungan aktivitas warga sekolah berjalan baik, perlu berbagai elemen pendukung. Salah satu elemen pendukung yang penting adalah prasarana infrastruktur TI. Selama ini prasarana TI diSMK sudah tersedia, namum belum ada manajemen pengelolaan prasarana TI mengacu pada tatakelola TI yang baik. Hal ini dikarenakan pihak SMK belum ada kepedulian terhadap tatakelola TI. Dalam jangka pendek memang sekolah tidak akan merasakan dampak yang signifikan bila tidak melakukan tatakelola TI.

Jika pengelolaan infrastruktur ini diabaikan, manajemen sekolah tidak tahu bagaimana kinerja lingkungan TI sekolah, kondisi hardware yang dimiliki, bagaimana perawatanya sehingga memperpanjang umur hardware. Kondisi software yang dipakai sebagai tool yang pendukung layanan administratif sekolah. Kebutuhan SDM yang berperan mengelola TI apakah sudah tercukupi, bagaimana skill SDM yang diperlukan saat ini dan masa akan datang. Faktor lain yang masih berkaitan yaitu proses pengadaan prasarana infrastruktur TI, bagaimana hubungan dengan rekanan sebagai penyedia prasarana TI tersebut. Risiko-risiko terkait infrastruktur TI tersebut dapat diminimalisir dengan adanya pengelolaan TI sejak dini. Manajemen sekolah dapat mendeteksi kapan harus mengubah dan memperbaharui infrastruktur TI sekolah, ketersedian SDM dan dan pengembangan skill nya. Pemilihan rekanan dan kontrak kerjasama yang baik dalam hal pengadaan infrastruktur TI akan membuat rasa aman bagi sekolah.

Melihat pentingnya infrastruktur TI di lembaga sekolah SMK, maka perlu dilakukan evaluasi terhadap infrastruktur TI. Penelitian ini menggunakan model pendekatan menggunakan framework COBIT 4.1. sebagai obyek evaluasi infrastruktur TI dipilih sekolah SMK dilingkup 
kabupaten Madiun. Tujuan dari penelitian ini untuk mengevaluasi tingkat kematangan infrastruktur TI di lembaga SMK, selanjutnya hasil evaluasi dijadikan sebagai dasar untuk memberikan rekomendasi tatakelola TI sesuai tingkat harapan yang diinginkan responden. COBIT 4.1. pemilihan framework cobit ini dikarenakan cobit merupakan framework populer yang digunakan para peneliti evaluasi tatakelola TI. COBIT memiliki 4 domain, yaitu : perencanaan (Planning and Organize), penerapan (Aquiring and Implement), layanan dan dukungan (Delivery and Support), dan pengawasan dan evaluasi (Monitorand Evaluate). Sesuai dengan permasalahan diatas, fokus penelitian ini pada pengelolaan infrastruktur TI dan pengadaan sumberdaya TI, kedua komponen tersebut masuk dalam domain AI (Aquiring and Implement) sub domain AI3 dan AI5 [1].

\section{METODOLOGI PENELITIAN}

Metode penelitian ini bersifat kuantitatif yaitu menggunakan model kematangan (maturity models) pada domain AI (Aquiring and Implement) infrastruktur TI[2].

\subsection{Alur Penelitian}

Adapun alur penelitian yang akan dilakukan sebagaimana terlihat pada Gambar 1. dibawah ini.

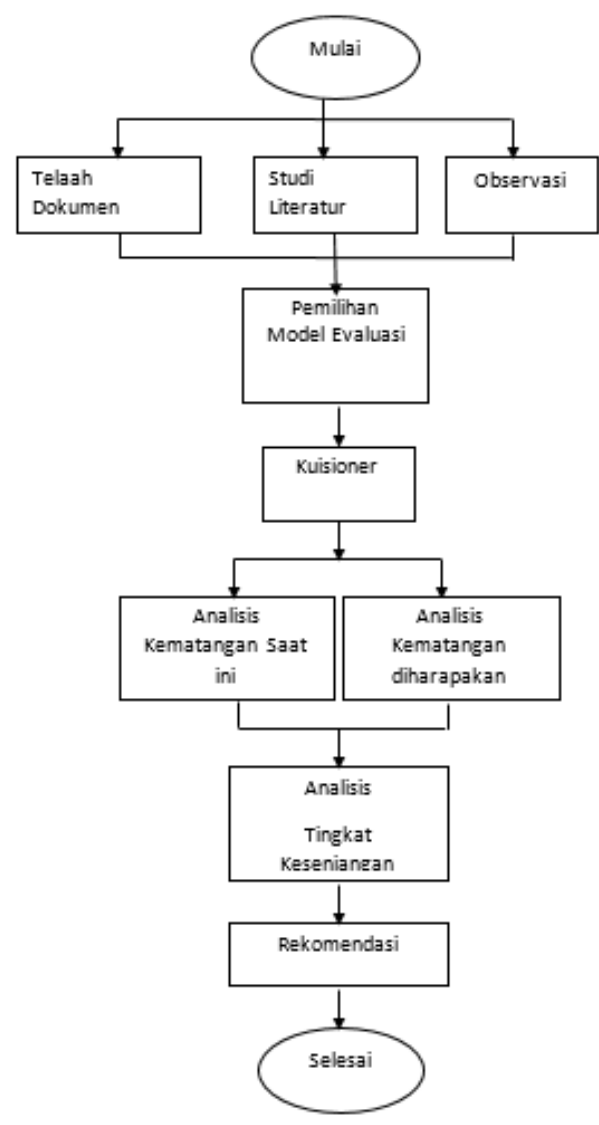

Gambar 1. Alur Penelitian 


\subsection{Lokasi Penelitian}

Lokasi penelitian di SMK Kabupaten Madiun yang dikhususkan pada aspek penerapan infrastruktur TI.

\subsection{Pengukuran}

Obyek yang dijadikan penelitian ini adalah penerapan infrastruktur TI pada SMKdi kabupaten Madiun, atribut yang digunakan untuk mencari tingkat kematangan COBIT adalahSumber daya manusia (people) dan Infrastruktur TI.

\subsection{Rancangan Penelitian}

Kuesioner ini merupakan alat untuk menggali informasi tingkat kematangan mengenai kegiatan-kegiatan yang berhubungan dengan penerapan infrastruktur TI di SMK Se-Kabupaten Madiun yang terdapat pada Tabel 1.

Tabel 1. Kuesioner Pengukuran Tingkat Kematangan

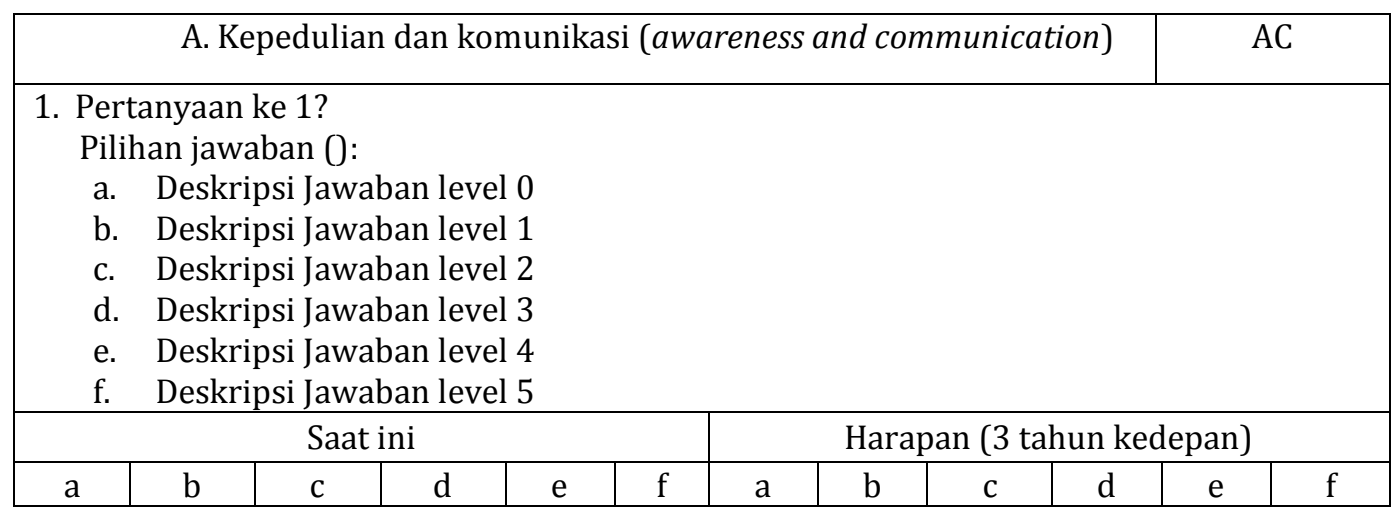

\subsection{Teknik Pengumpulan dan Analisa Data}

COBIT menyediakan alat untuk membantu organisasi yang melaksanakan penilaian diri dengan pendekatan potensi self-assesment. Selain itu bisa juga menggunakan penilaiain dengan maturity level dengan skala (0-Non-existenst, 1-Initial, 2-Repeatable, 3-Defined, 4-Managed dan 5Optimesed) [3]. Pada penelitian ini digunakan adalah penilaian maturity level. Penilaian tingkat kematangan (maturity level) dilakukan dengan mempertimbangkan nilai indek kematangan (maturity index) pada 6 atribut kematangan COBIT yang meliputi:
a. Awareness and Communication (AC)
b. Policies, Standards and Procedures (PSP)
c. Tools and Automation (TA)
d. Skill and Expertise (SE)
e. Responsibilities and Accountabilities (RA)
f. Goal Setting and Measurement (GSM) 
Kuisioner untuk pengukuran tingkat kematangan dikembangkan sedemikian rupa untuk mengetahui tingkat kematangan pada proses pengelolaan data baik untuk kondisi saat ini, maupun kondisi yang diharapkan, yang selanjutnya dijadikan dasar yang cukup untuk identifikasi prioritas peningkatan pada proses TI. Berdasarkan hasil wawancara dengan pihak manajemen TI sekolah, tingkat harapan (to-be) dalam kurun waktu 3 tahun kedepan, waktu (3 tahun) tersebut yang menjadi target tingkat harapan pihak manajemen TI dalam membenahi tata kelola TI penggunaan elearning menjadi lebih baik.

Perhitungan tingkat kematangan atribut dihitung dengan rumus. Indeks Kematangan Atribut setiap modul domain diperoleh dari menjumlahkan jumlah jawaban responden dikalikan dengan bobot skala kemudian dibagi dengan jumlah responden, seperti berikut ini :

$$
\text { tingkat kematangan atribut }=\frac{\sum \text { total jawaban } x \text { bobot }}{\text { jumlah responden }}
$$

Dimana bobot jawaban kuisioner memiliki nilai sebagai berikut :

Tabel 2. Bobot jawaban kuisioner

\begin{tabular}{|c|c|}
\hline Pilihan Jawaban & Bobot \\
\hline A & 0 \\
B & 1 \\
C & 2 \\
D & 3 \\
E & 4 \\
F & 5 \\
\hline
\end{tabular}

\subsection{Tata Kelola Teknologi Informasi (TI)}

Tatakelola TI merupakan upaya menjamin pengelolaan teknologi informasi agar mendukung selaras dengan strategi bisnis suatu enterprise yang dilakukan oleh dewan direksi, manajemen eksekutif, dan juga oleh manajemen TI [1]. Menurut Wim Van Grembergen (2009) IT Governance merupakan konsep yang berkembang dari sektor swasta, namun dengan berkembangnya penggunaan Teknologi Informasi (TI) oleh organisasi pemerintahan maka IT Governance juga harus diterapkan di sektor ini. Menurut Weill dan Ross IT Governance adalah suatu struktur hubungan dan proses untuk mengatur dan mengontrol perusahaan yang bertujuan untuk mencapai tujuan perusahaan yang telah ditetapkan dengan pertambahan nilai dengan tetap menyeimbangkan resiko-resiko dengan nilai yang didapatkan dari penerapan TI dan proses-prosesnya [4].

\subsection{Framework COBIT}

Standar COBIT (Control Objectives for Information and Related Technology) pertama kali dikemukakan oleh The Information Systems Audit 
and Control Association pada tahun 1996. COBIT merupakan salah satu metodologi yang memberikan kerangka dasar dalam menciptakan sebuah teknologi informasi yang sesuai dengan kebutuhan organisasi dengan tetap memperhatikan faktor-faktor lain yang berpengaruh [5].

\section{HASIL DAN PEMBAHASAN}

Pada bagian ini diberikan hasil penelitian yang dilakukan sekaligus dibahas secara komprehensip. Hasil bisa berupa gambar, grafik, tabel dan lain-lain yang mempermudah pembaca paham dan diacu di naskah. Jika bahasan terlalu panjang dapat dibuat sub-sub judul, seperti contoh berikut.

\subsection{Hasil Penelitian}

Setelah didapat hasil dari pengumpulan data kusioner, maka langkah selanjutnya data tersebut diolah menjadi suatu rekapitulasi, setiap atribut mempunyai nilai kontribusi atau pembobotan yang sama terhadap tingkat kematangan proses AI3 dan AI5.

\subsection{Analisis Kematangan}

Hasil rekapitulasi nilai kematangan proses AI3 Acquire and Maintain Technology Infrastructure terlihat pada Tabel 5.1, dannilai kematangan proses AI5 Procure IT Resources pada Tabel 3.

Tabel 3. Nilai kematangan proses AI3

\begin{tabular}{|c|c|c|c|c|}
\hline \multirow[t]{2}{*}{ Atribut } & \multicolumn{2}{|c|}{ Nilai kematangan } & \multicolumn{2}{|c|}{$\begin{array}{c}\text { Tingkat } \\
\text { kematangan }\end{array}$} \\
\hline & as-is & to be & as-is & to be \\
\hline Awareness and Communication (AC) & 2,3 & 4 & 2 & 4 \\
\hline Policies, Standards and Procedures (PSP) & 2,0 & 3 & 2 & 3 \\
\hline Tools and Automation (TA) & 2,2 & 4 & 2 & 4 \\
\hline Skill and Expertise (SE) & 2,0 & 4 & 2 & 4 \\
\hline Responsibilities and Accountabilities (RA) & 2,2 & 4 & 2 & 4 \\
\hline Goal Setting and Measurement (GSM) & 2,0 & 4 & 2 & 4 \\
\hline Rata-rata & 2,12 & 3,83 & 2 & 4 \\
\hline
\end{tabular}

Kajian tingkat kematangan saat ini dari hasil Tabel 4. nilai kematangan proses AI3 sebagai berikut :

1. Awareness and Communication $(A C)$

Adanya kepedulian dari staf TI untuk mulai melakukan pengelolaan infrastruktur TI. Pihak manajemen sekolah juga telah melakukan komunikasi dengan staf yang dianggap kompeten mengenai infrastruktur TI. Namun belum semuanya diakomodir.

2. Policies, Standards and Procedures (PSP)

Dalam hal pelaksanaan keamanan dan pemeliharaan infrastruktur TI dilakukan sebataskemampuan intuisi staf, karena belum ada prosedur kebijakan yang resmi. 
3. Tools and Automation (TA)

Pencatatan data monitoring pengelola infrastruktur TI sebagian telah dilakukan, pencatatan data dilakukan di excell.

4. Skill and Expertise (SE)

SDM TI untuk mengembangkan skill mengikuti diklat berdasarkan intuisi sendiri. Kemampuan kompetensi (skill) SDM yang menangani infrastruktur TI telah diidentifikasi dan diketahui pihak manajemen.

5. Responsibilities and Accountabilities (RA)

Tanggung jawab pekerjaan berdasarkan intuisi individu, masih terjadi ketimpangan dengan tugas lain.

6. Goal Setting and Measurement (GSM)

Tujuan pengelolaan infrastruktur TI sebagian sudah jelas namun belum lengkap. Masih sedikit kegiatan pengawasan/ monitoring terkait pengelolaan infrastruktur TI.

Tabel 4. Nilai kematangan proses AI5

\begin{tabular}{|l|c|c|c|c|}
\hline \multirow{2}{*}{\multicolumn{1}{|c|}{ Atribut }} & \multicolumn{2}{c|}{ Nilai kematangan } & \multicolumn{2}{c|}{ Tingkat kematangan } \\
\cline { 2 - 5 } & as-is & to be & as-is & to be \\
\hline Awareness and Communication (AC) & 1,3 & 3 & 1 & 3 \\
\hline Policies, Standards and Procedures (PSP) & 1,2 & 3 & 1 & 3 \\
\hline Tools and Automation (TA) & 1,2 & 3 & 1 & 3 \\
\hline Skill and Expertise (SE) & 1,3 & 3 & 1 & 3 \\
\hline Responsibilities and Accountabilities (RA) & 1,2 & 3 & 1 & 3 \\
\hline Goal Setting and Measurement (GSM) & 1,0 & 2 & 1 & 2 \\
\hline Rata-rata & 1,2 & 2,83 & 1 & 3 \\
\hline
\end{tabular}

Kajian tingkat kematangan saat ini dari hasil pada Tabel 4. nilai kematangan proses AI5 sebagai berikut:

1. Awareness and Communication (AC)

Pihak manajemen sekolah telah menyadari perlunya ada prosedur atau kebijakan,

Hal ini terbukti dengan adanya wacana identifikasi kebutuhan prosedur kontrak dengan rekanan pengadaan/jasaprasaran sumberdaya TI (hardware dan software).

2. Policies, Standards and Procedures (PSP)

Prosedur mendasar dalam pengadaan pembelian prasarana TI dengan pihak ketiga telah dibuat.

3. Tools and Automation (TA)

Penggunaan media masa atau media sosial untukpengadaan prasarana TI.

Namun tidak ada toolaplikasi untuk menentukan siapa rekanan pengadaan prasarana TI.

4. Skill and Expertise (SE)

Dalam pemilihan pihak rekanan/pemasok prasarana TI, manajemen sekolah telah memiliki kriteria dasar sesuai kebutuhan. 
5. Responsibilities and Accountabilities (RA)

Pihak manajemen sekolah yang bertanggungjawab mengadakan lelang. Belum ada staf TI khusus yang dibentuk mengadakan kontrak kerjasama dengan pemasok.

6. Goal Setting and Measurement (GSM)

Tujuan pengadaan prasarana TI telah didefinisikan.

\subsection{Rekomendasi Perbaikan}

Rekomendasi perbaikan dilakukan secara bertahap, disesuaikan dengan kondisi dan kemampuan instansi sekolah masing-masing. Berikut skenario rekomendasi perbaikan yang dapat dijadikan acuan perbaikan infrastruktur TI pada subdomain AI3.

Tabel 5. Rekomendasi perbaikan

\begin{tabular}{|c|c|c|c|c|}
\hline No & Atribut & $\begin{array}{c}\text { Tahun } \\
\text { ke1 }\end{array}$ & $\begin{array}{c}\text { Tahun } \\
\text { ke2 }\end{array}$ & $\begin{array}{c}\text { Tahun } \\
\text { ke3 }\end{array}$ \\
\hline 1 & $\begin{array}{l}\text { Awareness and Communication }(A C) \\
\text { - Pihak manajemen sekolah dan staf } \\
\text { TIberkomunikasi dan berdiskusi mencari solusi } \\
\text { terbaik menangani permasalahan pengelolaan } \\
\text { infrastruktur IT. } \\
\text { - Perbaikan, perawatan, kebutuhan, } \\
\text { ketersediaan serta keamanan(hardwaredan } \\
\quad \text { software). } \\
\text { - Kebutuhan dan peningkatan SDM TI } \\
\text { - Implementasi SOP terkait pengelolaan } \\
\text { infrastruktur TI di sekolah. }\end{array}$ & $\sqrt{ }$ & & $\sqrt{ }$ \\
\hline 2 & $\begin{array}{l}\text { Policies, Standards and Procedures (PSP) } \\
\text { - Prosedurpengelolaan infrastruktur TI yang } \\
\text { meliputi keamanan, perawatan, pengadaan } \\
\text { hardware dan software didokumentasikan. } \\
\text { - Membuat SOP pengelolaan infrastruktur TI yang } \\
\text { mengacu standart pengelolaan TI, jika perlu } \\
\text { melibatkan pihak ekternal yang kompeten. }\end{array}$ & $\sqrt{ }$ & $\sqrt{ }$ & \\
\hline 3 & $\begin{array}{l}\text { Tools and Automation (TA) } \\
\text { - Pencatatan data monitoring pengelolaan } \\
\text { infrastrukur TI dibuat berbasis aplikasi. } \\
\text { - Pencatatan data monitoring pengelolaan } \\
\text { infrastrukur TI dibuat berbasis berbasis online } \\
\text { dan terdistribusi langsung ke pihak yang } \\
\text { berkepentingan. }\end{array}$ & $\sqrt{ }$ & & $\sqrt{ }$ \\
\hline 4 & $\begin{array}{l}\text { Skill and Expertise (SE) } \\
\text { - Mendata kebutuhan kemampuan kopetensi yang } \\
\text { diperlukan SDM staf TI, mengadakan pelatihan } \\
\text { sesuai kopetensi yang diperlukan } \\
\text { meskipuntingkat lokal. } \\
\text { - Diberikan keleluasaan bagi SDM untuk } \\
\text { mengikuti pelatihan resmi (mengirim ke diklat) } \\
\text { guna meningkatkan kompetensi SDM TI. }\end{array}$ & & $\sqrt{ }$ & $\sqrt{ }$ \\
\hline 5 & Responsibilities and Accountabilities $(R A)$ & & & \\
\hline
\end{tabular}


Jurnal Sains Komputer \& Informatika (J-SAKTI)

Volume 3 Nomor 1 Maret 2019, pp. 80-90

ISSN:2548-9771/EISSN:2549-7200

http://tunasbangsa.ac.id/ejurnal/index.php/jsakti

\begin{tabular}{|c|c|c|c|}
\hline & $\begin{array}{l}\text { - Pengelola infrastruktur TI sekolah hendaknya } \\
\text { dipisahkan dengan pengelola infrastruktur } \\
\text { gedung sekolah, sehingga fokus pengembangan } \\
\text { infrastrutur TI lebih optimal. } \\
\text { - Adanya pendelegasian tugas dan tanggungjawab } \\
\text { yang jelas pengelolaan infrastruktur TI. } \\
\end{array}$ & $\sqrt{ }$ & $\sqrt{ }$ \\
\hline 6 & $\begin{array}{l}\text { Goal Setting and Measurement (GSM) } \\
\text { - Dibuatnya indikator tujuan pengelolaan } \\
\text { infrastruktur TI secara menyeluruh dan lengkap } \\
\text { (pengelola, perawatan, pengadaanhardware dan } \\
\text { software serta peningkatan SDM). } \\
\text { - Monitoring tujuan pengelolaan infrastruktur TI } \\
\text { telah mengacu pada framework tatakelola TI. }\end{array}$ & $\sqrt{ }$ & $\sqrt{ }$ \\
\hline
\end{tabular}

Adapun rekomendasi perbaikan pada subdomain AI3 dapat digambarkan seperti pada Gambar 2. Grafik target maturity level AI3.

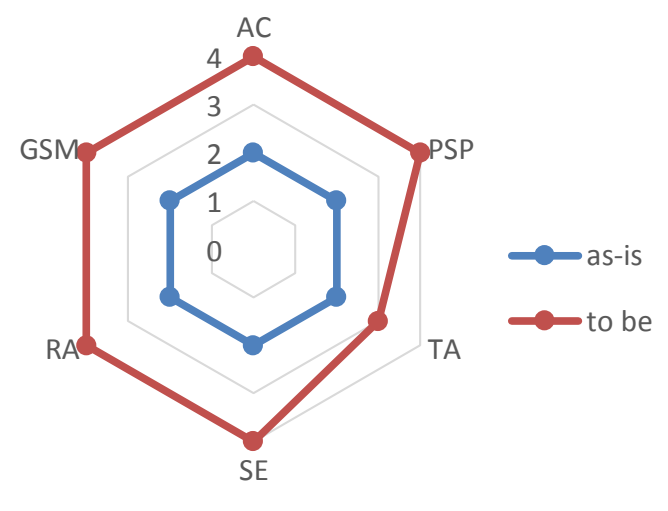

Gambar 2. Grafik target maturity level AI3

Sedangkan skenario rekomendasi perbaikan yang dapat dijadikan acuan perbaikan infrastruktur TI subdomain AI5 adalah :

\begin{tabular}{|c|l|c|c|c|}
\hline No & Atribut & $\begin{array}{c}\text { Tahun } \\
\text { ke1 }\end{array}$ & $\begin{array}{c}\text { Tahun } \\
\text { ke2 }\end{array}$ & $\begin{array}{c}\text { Tahun } \\
\text { ke3 }\end{array}$ \\
\hline 1 & $\begin{array}{l}\text { Awareness and Communication (AC) } \\
\text { Pihak manajemen sekolah membuat } \\
\text { prosedur/kebijakan standar terkait kerjasama dengan } \\
\text { pihak/rekananpengadaan prasarana TI. } \\
\text { Terkait kebijakan kerjasama dengan pihak rekanan } \\
\text { pengadaan prasarana TI,dikomunikasi dengan staf } \\
\text { TI sehingga kebijakan lebih sempurna. }\end{array}$ & $\sqrt{ }$ & \\
\hline 2 & $\begin{array}{l}\text { Policies, Standards and Procedures (PSP) } \\
\text { Dibuat prosedur kontrak kerjasamadengan pihak } \\
\text { rekanan terkait pengadaan prasarana TI. }\end{array}$ & $\sqrt{ }$ & \\
$\begin{array}{l}\text { Pengembangan prosedur kontrak kerjasamayang } \\
\text { melibatkan pihak rekanansebaiknya ada peninjauan } \\
\text { oleh penasehat hukum. }\end{array}$ & & $\sqrt{ }$ & \\
\hline 3 & $\begin{array}{l}\text { Tools and Automation (TA) } \\
\text { Penggunaan tool aplikasi untuk kerjasama yang }\end{array}$ & & $\sqrt{ }$ \\
\hline
\end{tabular}

Rekomendasi Perbaikan Infrastruktur di SMK dengan COBIT 4.1 (Dwiyono Ariyadi) |88 
Jurnal Sains Komputer \& Informatika (J-SAKTI)

Volume 3 Nomor 1 Maret 2019, pp. 80-90

ISSN:2548-9771/EISSN:2549-7200

http://tunasbangsa.ac.id/ejurnal/index.php/jsakti

\begin{tabular}{|c|c|c|c|c|}
\hline & $\begin{array}{l}\text { melibatkanpihak rekanan pengadaan/jasa sarana TI } \\
\text { mulai dikenalkan. } \\
\text { - Pengadaan/jasa prasaran TI dengan pihak rekanan } \\
\text { diusahakan dilakukan secara online berbasis } \\
\text { website. }\end{array}$ & & & $\sqrt{ }$ \\
\hline 4 & $\begin{array}{l}\text { Skill and Expertise }(S E) \\
\text { - Pihak manajemen sekolah menentukan standar } \\
\text { kualitas bagi calon rekanan pengadaan/jasa } \\
\text { prasarana TI. } \\
\text { - Pemilihan kriteria pihak rekanan pengadaan/jasa } \\
\text { prasarana TIdilakukan adil dan resmi untuk } \\
\text { memastikan kelayakan dengan proses bisnis } \\
\text { sekolah. }\end{array}$ & $\sqrt{ }$ & $\sqrt{ }$ & \\
\hline 5 & $\begin{array}{l}\text { Responsibilities and Accountabilities }(R A) \\
\text { - Adanya staf khusus yang mengkaji terkait } \\
\text { kontrakkerjasama serta pemilihan rekanan pemasok } \\
\text { prasarana TI. } \\
\text { - Melakukan evaluasi kontrak melibatkan pen]asehat } \\
\text { hukum. }\end{array}$ & & $\sqrt{ }$ & $\sqrt{ }$ \\
\hline 6 & $\begin{array}{l}\text { Goal Setting and Measurement (GSM) } \\
\text { - Dilakukan monitoring oleh pihak manajemen } \\
\text { terkaitkebijakan kontrak dengan rekanan } \\
\text { pengadaan/jasa prasarana TI. } \\
\text { - Indikator monitoring kontrak yang melibatkan pihak } \\
\text { rekanan sebaiknya mulai mengacu penggunaan } \\
\text { metode pengukuran. }\end{array}$ & & $\sqrt{ }$ & $\sqrt{ }$ \\
\hline
\end{tabular}

Adapun rekomendasi perbaikan pada subdomain AI5 dapat digambarkan seperti pada gambar 3. Grafik target maturity level AI5.

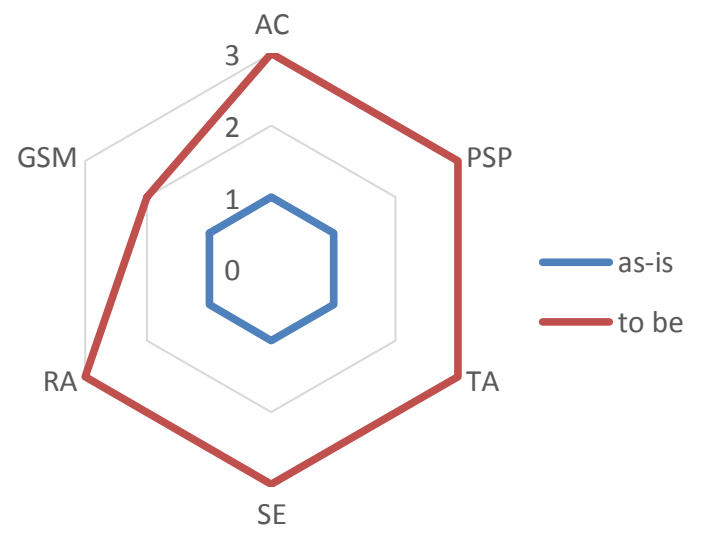

Gambar 3. Grafik target maturity level AI5

\section{SIMPULAN}

Adapun kesimpulan pada penelitian ini adalah tingkat kematangan pengelolaan infrastruktur TI di SMK madiun untuk sub domain AI3 berdasarkan 6 atribut kematangan AC, PSP, TA, SE, RA, GSM rata-rata saat ini berada pada level2 yaitu Repeatable but Intuitive. Sedangkan sub domain AI5 
berada pada level 1 yaitu initial/ adhoc. Adapun target harapan yang ingin dicapai pada tiga tahun kedepan adalah sebagai berikut, target untuksub domain AI3 bisa mencapai pada level4 yaitu managed and measurable. Pada tahap ini manajemen sekolah mengawasi dan mengukur hal-hal yang telah dipenuhi dengan prosedur yang telah dibuat, diantaranya prosedur pemeliharaan, keamanan, perencanaan infrastruktur TI, serta mengambil tindakan ketika proses tidak berjalan dengan efektif.Sedangkan sub domain AI5 target yang ingin dicapai pada level 3 yaitu Defined Process. Tahap ini manajemen SMK telah membuat prosedur untuk pemilihan rekanan serta kontrak kerjasama dengan pihak rekanan terkait pengadaan prasarana TI. Prosedur yang sesuai standar kontrak kerjasama dengan rekanan telah diformalkan dan didokumentasikan.

Langkah efektif yang harus dilakukanpihak SMK untuk dapat mencapai tingkat kematangan harapan yaitu mengacu pada rekomendasi perbaikan tatakelola TI yang dibuat. Untuk subdomain AI3, tahap ke 1, berusaha mencapai target level 3 Defined Process, selanjutnya setelah berhasil di tahap ke1 dilanjut tahap ke 2 yaitu upaya mencapai level 4 managed and measurable. Untuk subdomain AI5, tahap ke 1, berusaha mencapai target level 2 yaitu Repeatable but Intuitive, selanjutnya setelah berhasil di tahap ke1 dilanjut tahap ke 2 yaitu upaya mencapai level 3 Defined Process.

\section{DAFTAR PUSTAKA}

[1] Surendro, K. (2009). Implementasi Tata Kelola Teknologi Informasi. Informatika.

[2] Pedivera, A. (2003). The COBIT Maturity Model in a Vendor Evaluation Case. Information System Control Jurnal. Vol 3.

[3] ITGI. (2007). COBIT ver.4.1: Framework, Control Objectives, Management Guidelines, Maturity Models. Rolling meadow.

[4] Wibowo, M. P. (2008). Analisis Tingkat Kematangan (Maturity Level) Pengawasan dan Evaluasi Kinerja Teknologi Informasi Otomasi Perpustakaan dengan Cobit. Universitas Indonesia.

[5] Marita, S. L., \& Riyanto, Y., (2017). Evaluasi Tata Kelola Teknologi Informasi dengan Menggunakan Kerangka COBIT 4.0 Domain DS (Delivery And Support) dan Me (Monitoring Evaluation). Jurnal Ilmu Pengetahuan Dan Teknologi Komputer. 